\title{
IMPLEMENTASI KONSEP LEAN MANUFACTURING GUNA MENGURANGI PEMBOROSAN DI LANTAI PRODUKSI
}

\author{
Almer Panji Pradana, Mochammad Chaeron, M. Shodiq Abdul Khanan \\ Jurusan Teknik Industri, Fakultas Teknik Industri \\ Universitas Pembangunan Nasional "Veteran" Yogyakarta \\ Jl. Babarsari 2 Tambakbayan, Yogyakarta, 55281 \\ Telp. (0274) 485363 Fax.: (0274) 486256
}

\begin{abstract}
ABSTRAK
CV Marga Jaya (Pabrik II) adalah perusahaan yang bergerak di bidang pembuatan paving/conblock secara masal. CV Marga Jaya (Pabrik II) selalu berusaha mengurangi pemborosan yang terjadi selama proses produksi paving/conblock. Pemborosan yang terjadi antari lain, adanya produksi berlebih, transportasi, waktu menunggu, dan cacat yang berlebih.

Lean Manufacaturing merupakan pendekatan yang bertujuan untuk merampingkan proses dengan mengurangi pemborosan yang terjadi selama proses produksi. Pendekatan konsep lean manufacturing dimulai dengan membuat big picture mapping, dilanjutkan dengan waste assessment model (WAM), diagram cause and effects, value stream analysis tools (VALSAT), usulan perbaikan waste yang terjadi, dan pembuatan descrete event simulation (DES).

Hasil yang didapat bahwa waktu menunggu yang terjadi diperbaiki dengan menggunakan conveyor, produksi berlebih yang terjadi diperbaiki dengan melakukan perencanaan produksi, dan cacat berlebih yang terjadi diperbaiki dengan menggunakan $5 \mathrm{~W}+1 \mathrm{H}$ dengan sebelumnya menggunakan konsep lean six sigma dan didapat nilai sigma sebesar 4,31 sigma. Simulasi proses menunjukkan dengan mengurangi pemborosan, kemampuan produksi naik 15,36\% (penjemuran 30 hari) dan 147,20\% (penjemuran 7 hari).
\end{abstract}

Kata kunci: pemborosan, lean manufacturing, lean six sigma

\section{PENDAHULUAN}

Lean Manufacturing merupakan suatu pendekatan sistemik dan sistematik untuk mengidentifikasi dan menghilangkan pemborosan melalui perbaikan secara terus menerus (continuous improvement). Metode ini ideal untuk mengoptimalkan performansi dari sistem dan proses produksi karena mampu mengidentifikasi, mengukur, menganalisa, dan mencari solusi perbaikan. Konsep dasar dari lean adalah eliminasi atau mengurangi pemborosan. Shigeo Shingo mengidentifikasi keberadaan tujuh jenis pemborosan.

CV Marga Jaya (Pabrik II) merupakan perusahaan yang memproduksi paving/conblock. Sistem produksi yang digunakan adalah sistem produksi masal. Dengan begitu produk akan terus diproduksi sebelum ada pelanggan dan produk akan terus menumpuk di gudang barang jadi. Kejadian tersebut merupakan pemborosan produk berlebih. Dan juga pada kondisi saat ini terjadi pemborosan lain, yaitu waktu menunggu, cacat berlebih, dan transportasi.
Pemborosan yang terjadi saat ini harus dikurangi karena tidak mempunyai nilai tambah terhadap produk yang dihasilkan. Setiap permborosan mempunyai usulan perbaikan masing-masing. Dan untuk mengetahui kemampuan produksi setiap lini produksi setelah perbaikan terhadap pemborosan, maka dilakukan simulasi sistem produksi.

\section{LANDASAN TEORI}

1. Konsep Lean

Konsep lean adalah sekumpulan peralatan dan metode yang dirancang untuk mengeliminasi pemborosan, mengurangi waktu tunggu, memperbaiki performance, dan mengurangi biaya (Willian, 2006). Lean mengkaji aliran pekerjaan atau tugas dari mulai perancangan sampai dengan produk diterima konsumen agar dapat berjalan lancar dan tidak mengalami pemberhentian atau pengembalian yang disebabkan karena cacat atau waste (Muhsin dkk, 2018). Tujuan dari penerapan lean adalah untuk 
meningkatkan kualitas, meningkatkan produktivitas, meningkatkan kemampuan memperoleh keuntungan/profit, dan meningkatkan daya saing pasar.

\section{Big Picture Mapping}

Big Picture Mapping adalah suatu tools digunakan untuk menggambarkan suatu sistem secara keseluruhan berserta aliran nilai (value stream) yang terdapat dalam perusahaan. Dengan Big Picture Mapping, dapat diketahu ialiran informasi dan fisik dalam sistem, lead time yang dibutuhkan dari masing-masing proses yang terjadi. Data tersebutdi dapat dari interview dengan petugas terkait dan observasi lapangan. Tujuan dari Big Picture Mapping adalah untuk membuat dan menyalurkan produk atau jasa kepada konsumen akhir.

\section{Jenis-jenis Pemborosan}

Secara umum terdapat 7 jenis pemborosan yang ada. Pemborosan yang dimaksud adalah overproduction, waiting time, transportation, processes, inventories, motion, dan defect. Overproduction yaitu memproduksi lebih daripada kebutuhan pelanggan insternal dan eksternal, atau memproduksi lebih cepat atau lebih awal daripada waktu kebutuhan pelanggan internal dan eksternal. Delays (waiting time) yaitu keterlambatan yang tampak melalui orang-orang yang sedang menunggu mesin, peralatan, bahan baku, supplier, perawatan/pemeliharaan (maintenance), dll; atau mesin-mesin yang sedang menunggu perawatan, orang-orang, bahan baku, peralatan, dll. Transportation yaitu memindahkan orang atau barang ketempat yang sangat jauh dari satu proses ke proses berikut yang dapat mengakibatkan waktu penanganan material bertambah. Processes yaitu mencakup proses-proses tambahan atau aktivitas kerja yang tidak perlu atau tidak efisien. Inventories yaitu pada dasarnya inventories menyembunyikan masalah dan menimbulkan aktivitas penanganan tambahan yang seharusnya tidak diperlukan. Inventories juga mengakibatkan extra paperwork, extra space, dan extra cost. Motion yaitu setiap pergerakan dari orang atau mesin yang tidak menambah nilai kepada barang dan jasa yang akan diserahkan kepada pelanggan, tetapi hanya menambah biaya dan waktu saja. Defect yaitu scrap, rework, customer returns, customer dissatisfaction, dan desain yang tidak memenuhi kebutuhan pelanggan serta penambahan features yang tidak perlu (Intifada dan Witantyo, 2012).

\section{Value Stream Mapping}

Value Stream Mapping (VSM) adalah sebuah metode visual untuk memetakan jalur produksi dari sebuah produk yang didalamnya termasuk material dan informasi dari masing-masing stasiun kerja. VSM mampu memvisualisasikan aliran produk dan mengidentifikasi waste (George, 2002)

\section{Identifikasi Pemborosan}

Salah satu model untuk mengidentifikasi pemborosan adalah dengan menggunakan waste assessment model (WAM). Pada WAM terdapat 2 buah tahap dalam mengidentifikasi pemborosan, yaitu dengan menggunakan waste relationship matrix (WRM) dan waste assessment questionnaire (WAQ) (Rawabdeh, 2005).

\section{Diagram Cause And Effect}

Diagram cause and effect atau yang lebih dikenal dengan diagram fishbone digunakan untuk melihat hubungan sebab dan akibat yang ditinjau dari akar penyebab dan akar permasalahan dalam aktivitas kerja. Ada beberapa tipe dan bentuk dari diagram cause and effect yang berbasis pada formasi cabangcabang utamanya (bersifat kategori). Cabang utama dapat diartikan sebagai variabel-variabel proses yang disebut dengan '4M' (manpower, machines, material, methods) (Hidayat, 2007).

\section{Value Stream Analysis Tools (VALSAT)}

Pada prinsipnya, VALSAT digunakan sebagai alat bantu untuk memetakan secara detail aliran nilai (value stream) yang berfokus pada value adding process. Detail mapping ini kemudian dapat digunakan untuk menemukan penyebab waste yang terjadi (Hines and Rich, 1997)

\section{Peramalan}

Aktivitas peramalan merupakan suatu fungsi bisnis yang berusaha memperkirakan permintaan dan penggunaan produk sehingga produk-produk itu dapat dibuat dalam kuantitas yang tepat. Dengan demikian peramalan merupakan suatu dugaan terhadap permintaan yang akan datang berdasarkan pada beberapa variabel peramal, seperti berdasarkan data deret waktu historis.

\section{Kualitas}

Kualitas merupakan bagian dari semua fungsi produksi (pemasaran, manajemen sumber daya manusia, keuangan, dan lain-lain) dan memerlukan proses perbaikan secara terus menerus (contious improvement) yang terukur secara individual, organisasi, korporasi dan tujuan kinerja nasional (Ariyani, 2003). 


\section{Six Sigma}

Six sigma merupakan alat untuk memperbaiki kualitas produk dengan mereduksi tingkat kecacatan produk melalui 5 tahapan, yaitu: define (identifikasi masalah), measure (pengukuran performance kualitas), analyze (melakukan analisa terhadap penyebab kecacatan), improvement (melakukan usaha perbaikan untuk meningkatkan kualitas), dan control (pengendalian).

\section{Simulasi}

Simulasi merupakan salah satu cara untuk memecahkan persoalan yang dihadapi di dunia nyata. Metode yang dibangun untuk model dalam Operation Research dan System Analysis untuk mengambil keputusan dengan menggunakan berbagai analisis data. Pendekatan yang digunakan untuk memecahkan masalah yang tidak pasti dan kemungkinan jangka panjang yang tidak dapat diperhitungkan dengan seksama adalah dengan simulasi.

\section{METODOLOGI PENELITIAN}

Penelitian ini dilakukan pada Pabrik II CV Marga Jaya, Maguwoharjo, Sleman, Yogyakarta. Objek penelitian ini adalah produk paving/conblock. Permasalahan pada penelitian ini adalah terdapat pemborosanpemborosan yang tidak mempunyai nilai tambah terhadap produk. Penelitian ini dilakukan untuk mengurangi pemborosan yang terjadi dengan memberikan usulan perbaikan. Setelah itu dilakukan simulasi model untuk mengetahui berapa kemampuan lini produksi setelah dilakukan perbaikan.

Pada penelitian ini dibutuhkan beberapa da untuk dilakukan pengolahan data. Data yang dibutuhkan sebagai berikut:
a. Data produksi
b. Aliran produksi
c. Rincian proses
d. Penyebab terjadinya pemborosan

\section{PENGOLAHAN DATA DAN ANALISIS HASIL}

\section{Pengolahan data}

Pengolahan data yang dilakukan untuk mengidentifikasi pemborosan dan memberikan usulan perbaikan untuk mengurangi pemborosan yang terjadi. Pengolahan data dilakukan dengan tahapan sebagai berikut:

a. Membuat rincian proses produksi paving/conblock dengan menyertakan nama kegiatan, waktu, jarak, jumlah operator, dan jenis kegiatan.

b. Membuat big picture mapping berdasarkan rincian proses yang dibuat sebelumnya. Dan juga membuat membuat tanda atau rencana perbaikan yang akan dilakukan berdasarkan big picture mapping.

c. Mengolah data dari waste relationship matrix dan waste assessment modeluntuk mengidentifikasi dan mengurutkan pemborosan berdasarkan waste assessment model.

d. Menentukan penyebab dari pemborosan yang terjadi dengan menggunakan diagram fishbone.

e. Memberiakan usulan perbaikan terhadap pemborosan yang terjadi dan terpilih.

f. Membuat simulasi dari perbaikan yang dilakukan.

\section{Analisis Hasil}

a. Perbaikan yang telah dilakukan Dari hasil perhitungan yang dilakukan pad areduksi waste, dapat dianalisis perbaikan apa saja yang telah dilakukan adalah sebagai berikut:

1. Untuk usulan reduksi waiting time (delays), yaitu dengan mengganti metode perpindahan lokasi pengeringan - lokasi pencetakan. Perubahan yang dilakukan adalah semula menggunakan tenaga manusia, diganti dengan menggunakan conveyor. Penggunaan conveyor diterapkan langsung pada proses simulasi pada penelitian ini. Dan terbukti, dengan penggunaan conveyor tersebut dapat memperlancar proses produksi. Usulan scenario terbaik yaitu pada skenario 3 dengan lama waktu penjemuran 30 hari dan skenario 6 dengan lama waktu penjemuran 7 hari. Pada skenario 3 perusahaan mampu memproduksi 14000 pcs dan pada skenario 6 perusahaan mampu memproduksi 30000. Kedua scenario tersebut menunjukan peningkatan produksi sebesar $15,36 \%$ dan $147,20 \%$.

2. Usulan perbaikan reduk siover production, yaitu dengan meramalkan permintaan paving/conblock. Dengan harapan 
dengan peramalan tersebut, perusahaan tidak lagi memproduksi paving/conblock secara berlebih dan cepat atau lambat perusahaan harus mampu bersaing dengan competitor menggunakan sistem make to order.

3. Usulan perbaikan reduksi defect, yaitu dengan menggunakan metode six-sigma. Dari penerapan metode six-sigma, didapat hasil 4,31 sigma. Kondisi tersebut sudah cukup baik, akan tetapi untuk mewujudkan program defect tidak lebih besardari 3,4 DPMO, maka peneliti menggunakan $5 \mathrm{~W}+1 \mathrm{H}$ untuk improvement. Dengan metode tersebut, semua aspek akan diteliti dan diberikan usulan perbaikan. Sehingga program defect tidak lebih besard ari 3,4 DPMO dapat segera terwujud.

b. Model simulasi

Analisis akan dilakukan dengan melihat hasil simulasi yang telah dilakukan berdasarkan model-model simulasi yang dibuat. Terdapat 6 skenario yang dibuat untuk mengurangi waktu proses pada lokasi penyimpanan alas cetak selesai digunakan dan lokasi alas cetak siap digunakan. Ke-enam skenario yang sudah di uji bon ferroni menyatakan bahwa keenam scenario tersebut dapat diterima/diaplikasin pada CV Marga Jaya.

\section{KESIMPULAN}

Hasil dari penerapan konsep lean manufacturing pada proses produksi paving/conblock di Pabrik II, CV Marga Jaya adalah:

1. Proses identifikasi pemborosan yang dilakukan menggunakan Waste Assessment Model didapatkan urutan waste yang terjadi di Pabrik II, CV Marga Jaya. Dipilih 3 pemborosan teratas untuk dilakukan perbaikan. 3 pemborosan teratasadalah waiting time, overproduction, dan defect.

2. Usulan perbaikan yang dilakukan untuk mengurangi waste terpilih adalah dengan:

a. Waiting time: usulan perbaikan yang dilakukan adalah dengan merubah metode pengiriman alas cetak dari lokasi alas cetak selesai digunakan ke lokasi alas cetak siap digunakan. Perbaikan yang dilakukan adalah dengan menggunakan conveyor. Dengan menggunakan conveyor proses produksi menjadi lebih lancer karena mesin cetak tidak berhenti dalam beroperasi.

b. Overproduction: usulan perbaikan yang dilakukan adalah dengan melakukan peramalan permintaan. Dengan diramalkannya permintaan, perusahaan mampu menjadwalkan produksi tiap bulannya. Peramalan dilakukan menggunakan software POM-QM. Metode terpilih adalah dengan metode exponential smoothing $\alpha=0,8$ dengan nilai MAD sebesar 27818,54.

c. Defect: usulan perbaikan yang dilakukan adalah dengan mengetahui terlebih dahulu nilai sigma menggunakan metode lean six-sigma. Dengan metode six-sigma diketahui nilai sigma sebesar 4,31 sigma. Setelah diketahui nilai sigma, langkah selanjutnya adalah analisis dari penyebab cacatnya. Dan langkah terakhir adalah dengan melakukan improvement menggunakan metode $5 \mathrm{~W}+1 \mathrm{H}$.

3. Untuk mengetahui persentase kemampuan lini produksi memproduksi paving/conblock dengan usulan perbaikan yang dilakukan, maka dilakukan simulasi menggunakan PROMODEL. Dibuat 6 skenario perbaikan untuk mengetahui perbaikan yang diharapkan. Didapatkan skenario terpilih yaitu skenario 3 dengan peningkatan produksi sebesar 15,36\% apabila penjemuran dilakukan selama 30 hari dan skenario 6 dengan peningkatan produksi sebesar $147,20 \%$ apabila penjemuran dilakukan selama 7 hari.

\section{DAFTAR PUSTAKA}

Ariyani, 2003, Manajemen Kualitas, Pendekatan Sisi Kualitatif, PT Ghalia Indonesia, Jakarta.

Arnheiter, E., dan Maleyeff, J., 2005, The Integration of Lean Manufacturing and Six Sigma, The TQM Magazine, Vol. 17. 
Assauri, S., 1993, Teknik dan Metode Peramalan, Fakultas Ekonomi Universitas Indonesia, Jakarta.

Benitez, Y., et.al., 2007, Hospital Reduces Medication Error Using DMAIC and QFD, Quality Progress, Vol. 40.

Curry, J.J., 2007, A Lean Analysis Methodology Using Simulation, Society of Manufacturing Engineers

(SME) Technical Paper

Forrester, R., 1995, Implications of lean manufacturing for human resource strategy, Work Study, 44(3), 20-24.

Gaspersz, V., 2001, Total Quality Management, PT Gramedia Pustaka Utama, Jakarta.

Gaspersz, V., 2004, Production Planning and Inventory Control, PT Gramedia Pustaka, Jakarta.

Gaspersz, V., 2012, All in One Management Tool Book, Gramedia Pustaka Utama, Jakarta.

Gaspersz, V., Fontana., 2007, Lean Six Sigma for Manufacturing and Service Industries, PT Gramedia Pustaka Utama, Jakarta.

Ginting, R, 2007, Sistem Produksi, Graha Ilmu, Yogyakarta.

George, M. L., 2002, Lean Six Sigma: Combining Six Sigma Quality with Lean Speed, The McGraw-Hill, New York.

Herjanto, Eddy., 1999, Manajemen Produksi dan Operasi, Edisi Kedua, Grasindo, Jakarta.

Hidayat, A., 2007, Strategi Six Sigma "Peta Pengembangan Kualitas dan Kinerja Bisnis", PT Elex Media Komputindo, Jakarta.

Hines, P. and Rich N., 1997, The Seven Value Stream Mapping Tools, International Journal of Operations \& Production Management, 17(1), 46-64.

Ho, L., Chuang, C., 2006, A Study of Implementing Six Sigma Quality Management System in Government Agencies for Raising Service Quality, Journal of American Academy of Business, Vol. 10.

Khannan, M. S. A., dan Haryono, 2015, Analisis Penerapan Lean Manufakturing Untuk Menghilangkan Pemborosan Di Lini Produksi PT Adi Satria Abadi, Journal Rekayasa Sistem Industri, Vol 4, No.1, pp:47-54
Lazarus, I., Neely, C., 2003, Six Sigma Raising Bar, Managed Healthcare Executive, Vol.13.

Makridakis, S. dan Wheelwright S. C., 1994, Metode - Metode Peramalan untuk Manajemen, Binarupa Aksara, Jakarta.

Miller, G., Pawloski, J., \& Standrigde, C., 2010, A Case Study Of Lean, Sustainable Manufacturing, Journal of Industrial Engineering and Management, Vol 3, No. 1, pp: 11-32.

Muhsin, A., Djawoto, Priyo Susilo, Muafi., 2018, Hospital Performance Improvement Through The Hospital Information System Design, International Journal of Civil Engineering and Technology (IJCIET), Vol. 9, No.1, pp: 918-928

Nilakantasrinivasa, N., Nair, A., 2005, DMAIC Failure Modes, ASQ Six Sigma Forum Magazine, Vol. 4.

Rawabdeh, I. A., 2005, A Model for the Assessment of Waste in Job Shop Environments, International Journal of Operations \& Production Management, Vol. 25, pp. 800-822.

Samadi, A., 2010, Value Stream Mapping (Modul 5), Fakultas Teknik dan Manajemen Industri Institut Teknologi Bandung, Bandung.

Supranto, J., 1984, Metode Peramalan Kuantitatif untuk Perencanaan, PT Gramedia Pustaka, Jakarta.

Wahyuni, H.C. dkk, 2015, Pengendalian Kualitas, Graha Ilmu, Yogyakarta.

Waluyo, M., 2010, Kajian Waste pada Produksi Benang dengan Pendekatan Lean Manufacturing di PT XYZ Surabaya, pp. J1-J8, Proseding Semnas Waluyo Jatmiko, FTI UPNV Jatim, Surabaya.

William, T., 2006, Lean Sigma, Circuit Tree, Vol. 19.

Wilson, L, 2010, How to Implement Lean Manufacturing. The McGraw-Hill Companies, Inc., United States.

Woodard, T., 2005, Addressing Variation in Hospital Quality: Is Six Sigma the Answer, Journal of Healthcare Management, Vol. 50.

Yang, Kai., 2005, Design for Sig Sigma for Service, The McGraw-Hill Companies, Inc., United States. 